\title{
Study of antioxidant properties of suppositories with nicotinic acid in toxic liver damage
}

\author{
Yulia Shikova ${ }^{1,2 *}$, Victoria Petrova ${ }^{1}$, Anastasia Fedotova $^{1}$, and Ksenia Salazanova ${ }^{1}$ \\ ${ }^{1}$ FSBEI HE "Bashkir State Medical University" of the Ministry of Healthcare of Russia, 450008, Ufa, \\ Russia \\ ${ }^{2}$ State Autonomous Scientific Institution "Institute for strategic studies of the Republic of \\ Bashkortostan", 450008, Ufa, Russia
}

\begin{abstract}
New medicinal forms of acid are proposed nicotine original composition: suppositories with nicotine acid and propolis extract and suppositories with nicotine acid and pyridoxine hydrochloride. In conditions of toxic liver lesions are shown to activate free - radical processes oxidation. Against the background of medicinal forms application with acid nicotine observed expressed antioxidant effect. Keywords: suppositories, propolis extract, nicotine acid, antioxidant properties.
\end{abstract}

\section{Relevance}

A pathological condition in which the liver tissue is affected due to the influence exerted on them by a large amount of alcohol consumed by a person, the ingestion of various poisons, the frequent use of drugs, exposure to chemicals and radio radiation is called toxic liver damage. For treatment, detoxification therapy is widely used in combination with the use of hepatoprotectors, absorbents, diuretics, antispasmodics and other groups of drugs. At the same time, there is a constant search for effective medicines used both for prevention and treatment, and for rehabilitation in the recovery period after severe illnesses. In this case, a special role is assigned to drugs belonging to the number of endogenous compounds. Nicotinic acid has various pharmacological effects, among which hepatoprotective and detoxifying effects are distinguished. If signs of toxic effects on liver cells appear, then along with the use of nicotinic acid, it is recommended to include foods rich in vitamin B6 in food. In addition, it is advisable to combine nicotinic acid with natural antioxidants, for which we used propolis extract as a means of complex therapy. Therefore, we have proposed the following compositions: nicotinic acid - 0.05 ; pyridoxine hydrochloride -0.1 (or alcohol propolis extract - $0.4 \mathrm{ml}$ ); polyethylene glycol (PEG) 4000 - 0.7; polyethylene glycol (PEG) 1500 - 0.3; cremophor SO-40 - 1.25; lutrol F-68 - 0.75; emulsifier T-2 - 0.1 [1].

The developed compositions in the form of suppositories are recommended for the treatment of hemorrhoids and are distinguished by a number of advantages, namely, a wide range of biological and therapeutic activities: they accelerate tissue regeneration, reduce edema and spasms, dilate blood vessels, reduce the load on them, thereby providing an angioprotective effect, preventing the formation of blood clots, prevent or slow down the

*Corresponding author: shikmann@mail.ru 
development of inflammatory processes, have antioxidant and antibacterial effects, and the release of active substances occurs evenly, which explains the prolongation of their action.

\section{Materials and methods}

During the research, only components approved for medical use were used. Lutrol F-68, Cremophor CO-40, polyethylene glycol 4000, polyethylene glycol 1500, emulsifier T-2 were used as auxiliary substances in the composition of the dosage forms. PEG 4000 has been used as a thickener, softener, binder and glidant, and solubilizer. PEG 1500 is used as a binder. Emulsifier T-2 - stabilizer, emulsifier and plasticizer. Lutrol F-68 in the composition was a solubilizer (helping to improve dissolution). Cremophor CO-40 possesses surface-active properties, due to which it is able to increase the bioavailability of the active substances included in the composition, as well as significantly improve the structure of the solvent.

The experimental part of the work was carried out with the participation of outbred laboratory rats, male and female, whose weight was 240-280 g, the individuals were kept in a vivarium under standard conditions. In the course of the research, all existing ethical norms and recommendations for the humanization of experiments on animals, which were given in the European Convention for the Protection of Experimental Vertebrate Animals, were observed.

For six days, the rats were given intramuscular injections of carbon tetrachloride in the form of a $50 \%$ oil solution at the rate of 2.0 grams per kilogram of animal weight in order to reproduce toxic liver damage. As a result of this chronic poisoning, the liver significantly increases in size and an increase in lipid peroxidation is noted. The samples under study were injected in the form of a suspension prepared in isotonic solution (at the rate of 10 milligrams per 100 grams of animal weight) once into the stomach by intubation, or rectally in parallel with the introduction of carbon tetrachloride. On the seventh day, the experimental animals were sacrificed by decapitation under ether narcosis [2].

The content of Schiff bases was calculated relative to absorbance at $400 \mathrm{~nm}$ to optical density at $220 \mathrm{~nm}$. The oxidation indices reflecting the relative level of primary and secondary LPO products were calculated relative to the optical densities $\mathrm{E}_{278} / \mathrm{E}_{220}$ and $\mathrm{E}_{232} / \mathrm{E}_{220}$. The oxidizability of lipid extracts was calculated relative to the optical densities $\mathrm{E}_{232} / \mathrm{E}_{220}, \mathrm{E}_{278} / \mathrm{E}_{220}$, determined before and after the introduction of the mixture that initiates LPO and expressed in\% relative to the initial level, as well as relative to the activity of catalase [3].

The research was carried out jointly with the Federal State Budgetary Educational Institution of Higher Education "South Ural State Medical University" of the Ministry of Health of Russia, with the participation of the Dean of the Faculty of Pharmacy, Head of the Department of Pharmacy and Chemistry of the Faculty of Pharmacy, Ph.D., Associate Professor Simonyan E.V.

\section{Results and discussion}

We have proposed 14 different formulations, two of which were distinguished by the most complete release of nicotinic acid (table 1).

When selecting the optimal composition, special attention was paid to the following criteria: the time spent on complete dissolution, as well as the degree of release of nicotinic acid (table 1).

Method for preparing suppositories (composition 3, 10). In a water bath, the temperature of which does not exceed $70^{\circ} \mathrm{C}$, the auxiliary substances are melted: 
emulsifier T-2, PEG 4000, PEG 1500, lutrol F-68, Cremophor SO-40. Then, at a temperature of $45^{\circ} \mathrm{C}$, air bubbles are removed from the mixture; for this, the suppository mass is left and not stirred for 30 minutes. Next, nicotinic acid and alcoholic propolis extract (pyridoxine) are introduced. The active substances are introduced with constant stirring using a glass rod. In pre-cooled at a temperature of $3-5^{\circ} \mathrm{C}$ for 5 minutes, metal molds, pre-treated with a gauze swab soaked in vaseline oil, the resulting mass is poured at a temperature of $38-40^{\circ}$. The mixture hardens within 7-10 minutes in the refrigerator. The obtained suppositories have the correct shape, homogeneous, solid, have high bioavailability, complete dissolution takes 11 minutes in time (table 2), and the therapeutic effect is noticeable after administration after 15 minutes (table 3).

Table 1. Compositions of suppositories per 1 suppository

\begin{tabular}{|c|c|c|c|c|c|c|c|c|}
\hline \multirow{2}{*}{$\begin{array}{c}\text { Composition } \\
\text { No }\end{array}$} & \multicolumn{8}{|c|}{ Ingredients (for one suppository), $\Gamma$} \\
\hline & 弟 & 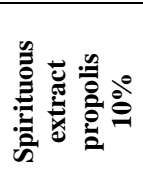 & 茯 & $\begin{array}{l}\text { PEG } \\
4000\end{array}$ & $\begin{array}{l}\text { PEG } \\
1500\end{array}$ & 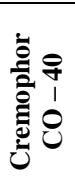 & 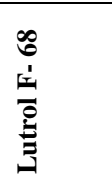 & 离 \\
\hline 1 & 0,5 & 0,4 & - & 1,0 & - & 1,25 & 0,75 & 0,1 \\
\hline 2 & 0,5 & 0,4 & - & 0,5 & 0,5 & 1,25 & 0,75 & - \\
\hline 3 & 0,5 & 0,4 & - & 0,7 & 0,3 & 1,25 & 0,75 & 0,1 \\
\hline 4 & 0,5 & 0,4 & - & 0,3 & 0,7 & 1,25 & 0,75 & 0,1 \\
\hline 5 & 0,5 & 0,4 & - & 0,6 & 0,4 & 1,25 & 0,75 & 0,1 \\
\hline 6 & 0,5 & 0,4 & - & 0,8 & 0,2 & 1,25 & 0,75 & 0,1 \\
\hline 7 & 0,5 & 0,4 & - & 0,5 & - & 1,0 & 1,0 & 0,1 \\
\hline 8 & 0,5 & - & 0,1 & 1,0 & - & 1,25 & 0,75 & 0,1 \\
\hline 9 & 0,5 & - & 0,1 & 0,5 & 0,5 & 1,25 & 0,75 & - \\
\hline 10 & 0,5 & - & 0,1 & 0,7 & 0,3 & 1,25 & 0,75 & 0,1 \\
\hline 11 & 0,5 & - & 0,1 & 0,3 & 0,7 & 1,25 & 0,75 & 0,1 \\
\hline 12 & 0,5 & - & 0,1 & 0,6 & 0,4 & 1,25 & 0,75 & 0,1 \\
\hline 13 & 0,5 & - & 0,1 & 0,8 & 0,2 & 1,25 & 0,75 & 0,1 \\
\hline 14 & 0,5 & - & 0,1 & 0,5 & - & 1,0 & 1,0 & 0,1 \\
\hline
\end{tabular}

Table 2. Determination of the time of complete dissolution of suppositories

\begin{tabular}{|c|c|}
\hline Composition No & Full dissolution time, minutes \\
\hline 1 & $6 \pm 0,5$ \\
\hline 2 & $9 \pm 0,2$ \\
\hline 3 & $11 \pm 0,2$ \\
\hline 4 & $9 \pm 0,5$ \\
\hline 5 & $9 \pm 0,5$ \\
\hline 6 & $10 \pm 0,2$ \\
\hline 7 & $9 \pm 0,5$ \\
\hline 8 & $6 \pm 0,5$ \\
\hline 9 & $9 \pm 0,5$ \\
\hline 10 & $11 \pm 0,3$ \\
\hline 11 & $9 \pm 0,5$ \\
\hline 12 & $9 \pm 0,2$ \\
\hline 13 & $10 \pm 0,2$ \\
\hline 14 & $9 \pm 0,5$ \\
\hline
\end{tabular}


Pharmaceutical availability was determined by diffusion into agar using 5\% bromothymol blue.

Table 3. Determination of pharmaceutical availability of suppositories

\begin{tabular}{|c|c|c|c|c|c|c|c|c|c|c|c|c|c|c|}
\hline \multirow[t]{2}{*}{ Time, min } & \multicolumn{14}{|c|}{ painted area diameter, $\mathrm{mm}$} \\
\hline & 1 & 2 & 3 & 4 & 5 & 6 & 7 & 8 & 9 & 10 & 11 & 12 & 13 & 14 \\
\hline 15 & 13 & 11 & 15 & 15 & 15 & 15 & 12 & 12 & 12 & 15 & 15 & 15 & 15 & 13 \\
\hline 30 & 15 & 13 & 18 & 17 & 17 & 17 & 14 & 13 & 13 & 18 & 17 & 17 & 17 & 15 \\
\hline 45 & 16 & 14 & 19 & 18 & 18 & 18 & 15 & 16 & 14 & 20 & 18 & 18 & 18 & 16 \\
\hline 60 & 18 & 15 & 21 & 19 & 19 & 19 & 17 & 18 & 15 & 21 & 19 & 19 & 19 & 18 \\
\hline 120 & 21 & 18 & 22 & 21 & 21 & 21 & 20 & 21 & 18 & 22 & 21 & 21 & 21 & 20 \\
\hline 180 & 23 & 20 & 24 & 22 & 21 & 21 & 22 & 23 & 20 & 24 & 22 & 21 & 21 & 22 \\
\hline
\end{tabular}

It is established that compositions No. 3 and No. 10 have optimal properties. Subacute liver damage is confirmed by an increase in liver mass. Against the background of toxic liver damage with carbon tetrachloride, a sharp increase in the content of MDA is observed against the background of a decrease in SOD (Table 4).

Table 4. Study of the effect of nicotinic acid on the LPO process in toxic liver damage

\begin{tabular}{|c|c|c|c|c|c|}
\hline Animal groups & $\begin{array}{c}\text { Liver } \\
\text { mass, g }\end{array}$ & $\begin{array}{l}\text { MDA, } \\
\mathrm{mmol} / \mathrm{l}\end{array}$ & $\begin{array}{c}\text { SOD, } \\
\text { AED/mg }\end{array}$ & $\begin{array}{c}\text { Diene } \\
\text { conjugates } \\
\text { (heptane phase } \\
\text { /isopropanol } \\
\text { phase), } \\
\text { absorbance unit }\end{array}$ & $\begin{array}{c}\text { Ketodienes and } \\
\text { conjugated trienes } \\
\text { (heptane phase } \\
\text { /isopropanol phase), } \\
\text { absorbance unit }\end{array}$ \\
\hline Intact animals & $6,91 \pm 0,26$ & $6,51 \pm 0,503$ & $1,423 \pm 0,106$ & $\begin{array}{c}0,518 \pm 0,0023 / 0,4 \\
86 \pm 0,042\end{array}$ & $\begin{array}{c}0,084 \pm 0,009 / 0,096 \pm 0 \\
, 0082\end{array}$ \\
\hline $\begin{array}{l}\text { Control with } \\
\text { toxic liver } \\
\text { damage }\end{array}$ & $11,51 \pm 0,41$ & $8,02 \pm 0,611$ & $0,595 \pm 0,158$ & $\begin{array}{c}0,597 \pm 0,026 / \\
0,529 \pm 0,038^{*}\end{array}$ & $\begin{array}{c}0,119 \pm 0,012 / \\
0,128 \pm 0,016\end{array}$ \\
\hline $\begin{array}{l}\text { Animals treated } \\
\text { with nicotinic } \\
\text { acid }\end{array}$ & $9,27 \pm 0,29^{*}$ & $7,13 \pm 0,307$ & $\begin{array}{c}0,912 \pm 0,126 \\
*\end{array}$ & $\begin{array}{c}0,532 \pm 0,007 / \\
0,509 \pm 0,048^{*}\end{array}$ & $\begin{array}{c}0,111 \pm 0,014 / \\
0,119 \pm 0,022\end{array}$ \\
\hline $\begin{array}{c}\text { Animals treated } \\
\text { with } \\
\text { suppositories } \\
\text { with nicotinic } \\
\text { acid and } \\
\text { pyridoxine } \\
\text { hydrochloride } \\
\end{array}$ & $8,55 \pm 0,16^{*}$ & $\begin{array}{c}7,08 \pm 0,252 \\
*\end{array}$ & $\begin{array}{c}0,961 \pm 0,076 \\
*\end{array}$ & $\begin{array}{c}0,525 \pm 0,026 / \\
0,496 \pm 0,009 *\end{array}$ & $\begin{array}{c}0,109 \pm 0,0089 / \\
0,118 \pm 0,068\end{array}$ \\
\hline $\begin{array}{l}\text { Animals treated } \\
\text { with } \\
\text { suppositories } \\
\text { with nicotinic } \\
\text { acid and } \\
\text { propolis extract }\end{array}$ & $8,31 \pm 0,14 *$ & $\begin{array}{l}6,88 \pm 0,213 \\
*\end{array}$ & $\begin{array}{c}0,980 \pm 0,121 \\
*\end{array}$ & $\begin{array}{c}0,523 \pm 0,017 / \\
0,502 \pm 0,039^{*}\end{array}$ & $\begin{array}{c}0,106 \pm 0,0093 / \\
0,116 \pm 0,0088\end{array}$ \\
\hline $\begin{array}{l}\text { Animals treated } \\
\text { with nicotinic } \\
\text { acid } \\
\text { suppositories }\end{array}$ & $8,92 \pm 0,16^{*}$ & $7,21 \pm 0,194$ & $\begin{array}{c}0,969 \pm 0,083 \\
*\end{array}$ & $\begin{array}{l}0,528 \pm 0,021 / \\
0,499 \pm 0,011^{*}\end{array}$ & $\begin{array}{c}0,107 \pm 0,0092 / \\
0,116 \pm 0,072\end{array}$ \\
\hline $\begin{array}{l}\text { Animals treated } \\
\text { with pyridoxine } \\
\text { hydrochloride } \\
\text { suppositories }\end{array}$ & $9,18 \pm 0,19 *$ & $7,05 \pm 0,27 *$ & $\begin{array}{c}0,922 \pm 0,126 \\
*\end{array}$ & $\begin{array}{l}0,529 \pm 0,011 / \\
0,501 \pm 0,027^{*}\end{array}$ & $\begin{array}{l}0,107 \pm 0,011 / \\
0,116 \pm 0,021\end{array}$ \\
\hline $\begin{array}{l}\text { Animals treated } \\
\text { with propolis } \\
\text { extract } \\
\text { suppositories }\end{array}$ & $9,06 \pm 0,13 *$ & $7,01 \pm 0,14 *$ & $\begin{array}{c}0,962 \pm 0,104 \\
*\end{array}$ & $\begin{array}{l}0,529 \pm 0,013 / \\
0,506 \pm 0,017^{*}\end{array}$ & $\begin{array}{c}0,109 \pm 0,0098 / \\
0,117 \pm 0,019\end{array}$ \\
\hline
\end{tabular}

* significant differences from the control group, $P<0.05$ 
The content of diene, ketodiene conjugates and conjugated dienes significantly increases. In animals that received nicotinic acid in the form of a substance, as well as dosage forms together with propolis extract, a pronounced detoxification effect is observed. Visually, the liver mass decreases in comparison with the control by $19.4 \%$ - with the introduction of nicotinic acid in the form of a substance, and by $22.5 \%$ - with the introduction of a rectal dosage form of nicotinic acid. The addition of propolis extract contributes to a greater reduction in liver weight (by 27.8\%). However, suppositories only with propolis extract contribute to a decrease in liver weight by only $21.3 \%$ compared to the control. The same results were observed in the study of the level of SOD, MDA, as well as POL products when the animals were administered the studied dosage forms [4]. In the combined presence of nicotinic acid and pyridoxine hydrochloride, a pronounced detoxification effect is also observed. Thus, the introduction of pyridoxine hydrochloride in the composition of suppositories together with nicotinic acid reduces the weight of the liver by $25.9 \%$, and in the case of using suppositories containing only pyridoxine hydrochlorideby $20.52 \%$.

\section{Conclusions}

1. Based on the complex of pharmaceutical and technological tests, new combined dosage forms containing nicotinic acid in the form of rectal suppositories are proposed.

2. The dosage forms were found with nicotinic acid and propolis extract, as well as nicotinic acid and pyridoxine hydrochloride, to have a detoxifying and antioxidant effect in toxic liver damage, which is manifested in a decrease in the level of diene, ketodiene conjugates and Schiff bases against the background of restoring the level of SOD and reducing the level of malondialdehyde.

\section{References}

1. Yu.V. Shikova, V.A. Likhoded, E.V. Simonyan, A.V. Epifanova, S. B.

Bakhtiyarova, R. A. Zaripov, Pharmacy 3 (2015)

2. A.N. Mironov. Guidelines for conducting preclinical studies of medicines. Part one (Grif i K, Moscow, 2012)

3. E.E. Dubinina, Medicinal chemistry questions 47, 6 (2001)

4. Yu.V. Shikova, V. A. Likhoded, R. R. Farkhutdinov, E. V. Simonyan, Yu.L. Baymurzina, A.V. Epifanova, A. G. NEVES DA SILVA, V. V. Petrova, E.V. Elova, Medical Observer of Bashkortostan. 8, 6 (2013) 